\title{
DESAIN SIPUTMATIKA DAN RANCANGAN LINTASAN BELAJAR SISWA SEKOLAH DASAR PADA MATERI SIMETRI PUTAR
}

\author{
Eka Zuliana ${ }^{1}$
}

Prodi Pendidikan Guru Sekolah Dasar, Fakultas Keguruan dan Ilmu Pendidikan

Universitas Muria Kudus, Indonesia

\section{Info Artikel}

Sejarah Artikel:

Diterima Maret 2017

Disetujui Mei 2017

Dipublikasikan Juni 2017

Keywords:

Siputmatika; Lintasan

Belajar; Simetri Putar

\begin{abstract}
The purposed of this research is to get the design of siputmatika and the design of learning trajectory of mathematics for rotary symmetry material. Siputmatika is a device that can help students to construct rotary symmetry. This device can be modified by elementary school students to build the concept, prove and be a tool in making learning trajectory of rotary symmetry. This research is a design research with pre eliminary design as the first stage. The literature review and study of concepts and appropriate media are used to design siputmatika. The result of this research is the design of learning trajectory for rotary symmetry material. Hypothetical learning trajectory is expected to be a tool and signs for the elementary school teachers in conducting learning process to help students construct their own concept of rotary symmetry using siputmatika.
\end{abstract}

\begin{abstract}
Abstrak
Tujuan penelitian ini adalah untuk mendapatkan desain siputmatika dan rancangan lintasan belajar matematika materi simetri putar. Siputmatika merupakan alat peraga simetri putar matematika. Alat peraga ini dapat diotak atik oleh siswa SD untuk membangun konsep, membuktikan dan menjadi alat dalam membuat lintasan belajar simetri putar. Penelitian ini merupakan design research dengan tahapan pertama pre eliminary design. Literature review dan studi tentang konsep dan media yang tepat digunakan untuk mendesain peraga siputmatika. Dari penelitian ini dihasilkan rancangan lintasan belajar (learning trajectory) materi simetri putar. Dugaan lintasan belajar ini diharapkan dapat menjadi rambu - rambu bagi guru SD dalam melaksanakan pembelajaran untuk membantu siswa mengkonstruk sendiri konsep simetri putar menggunakan siputmatika.
\end{abstract}

(C) 2017 Universitas Muria Kudus

\begin{tabular}{lr}
\hline Alamat korespondensi: & p-ISSN 2087-9385 \\
Program Studi Pendidikan Guru Sekolah Dasar & e-ISSN 2528-696X \\
Fakultas Keguruan dan Ilmu Pendidikan Universitas Muria Kudus & \\
Kampus UMK Gondangmanis, Bae Kudus Gd. L. 1t I PO. BOX 53 & \\
Kudus & \\
Tlp (0291) 438229 ex.147 Fax. (0291) 437198 & E-mail: eka.zuliana@umk.ac.id
\end{tabular}




\section{PENDAHULUAN}

Representasi bentuk benda simetri dan asimetri banyak ditemukan dalam kehidupan sehari - hari. Kupu - kupu, gunting dan benda lain di sekitar yang asimetri seperti sisir dan garpu mampu membantu siswa dalam membangun konsep simetri dan bukan simetri (asimetri) pada suatu benda. Dalam konteks ini, siswa terbatas pada pembangunan pengetahuan terkait 'bentuk benda simetri dan asimetri' yang ada di sekitar mereka. Heruman (2012:1) menyebutkan bahwa usia perkembangan siswa Sekolah Dasar (SD) masih terikat pada objek konkret yang dapat dengan mudah ditangkap oleh panca indranya. Oleh karena itu, melalui kegiatan melihat, mengamati, meraba, berfikir dan mengidentifikasi benda - benda sekitar tersebut siswa mampu membedakan mana benda sekitar yang simetri dan mana benda yang asimetri (tidak simetri).

Kesulitan belajar matematika yang sesungguhnya terjadi ketika siswa berhadapan dengan konsep matematika formal terkait kesimetrisan suatu bangun datar. Siswa masih melakukan hafalan konsep dalam belajar sumbu simetri, jumlah simetri lipat dan simetri putar suatu bangun datar. Sebagai akibatnya, banyak siswa mengalami kekeliruan dan terbolak baliknya konsep simetri, permasalahan lanjutan terjadi ketika siswa diminta untuk membuktikan posisi sumbu simetri, jumlah simetri lipat dan jumlah simetri putar suatu bangun datar (Bethari, 2015).

Kondisi ini memperlihatkan gap antara objek kajian matematika yang abstrak tentang konsep simetri bangun datar dengan tingkat berpikir kognitif siswa SD yang sesuai dengan teori Piaget dimana mereka lebih interest pada benda konkret (Piaget, 2000). Barrouillet (2015) juga menyebutkan bahwa siswa yang berada pada fase operational concrete lebih interest memanipulasi benda/objek konkret. Fase operational concrete mengakibatkan siswa SD lebih cenderung mengotak atik benda-benda konkret atau alat peraga yang dirancang secara spesifik sehingga dapat diotak-atik oleh siswa dalam memahami suatu konsep matematika (Sugiarto, 2009). Dengan memanipulasi benda, mereka secara tidak langsung telah mempelajari sesuatu dan mendapatkan pengetahuan baru tentang suatu konsep matematika. Kegiatan ini merupakan proses constructivisme dan penemuan kembali (reinvention) suatu konsep.

Untuk mengatasi kesenjangan tersebut diperlukan sebuah desain pembelajaran yang memfasilitasi dan menghantarkan siswa mengotak atik dan memanipulasi benda atau objek konkret untuk mempelajari konsep matematika yang bersifat abstrak dalam rangka membangun konsep simetri, pada khususnya dalam kajian ini dibahas tentang simetri putar.

Tujuan dari penelitian ini adalah untuk mendapatkan desain media simetri putar matematika (siputmatika) beserta rancangan lintasan belajarnya (learning trajectory).

Freudenthal (2006) menyatakan pengetahuan dan kemampuan matematis apabila dibangun diikuti dengan reinvention mampu memberikan motivasi kepada siswa dalam menumbuhkan sikap mengalami matematika sebagai aktivitas manusia. Zuliana (2013:150) menyebutkan reinvention merupakan bagian penting dalam pembelajaran matematika di SD. Larsen \& Zandieh (2008) juga menyebutkan bahwa pembangunan dan penemuan kembali konsep matematika dapat memberikan sebuah kerangka kerja yang berguna untuk memahami aktivitas matematika di ruang kelas dimana siswa secara aktif terlibat dalam pengembangan ide matematika dan memberikan desain heuristik proses reinventionnya.

$\begin{gathered}\text { Reinvention } \\ \text { selaras }\end{gathered}$ dengang dilakukan oleh
dengakteristik siswa selaras dengan karakteristik
constructivisme dan student centered learning $(S C L)$. Konstruksi dan rekonstruksi konsep membuat pembelajaran bermakna bagi siswa karena constructivisme mensyaratkan siswa untuk mengintegrasikan pengetahuan baru dengan pengetahuan yang sudah ada dalam struktur kognitif mereka (Novak, 2002:548). Siswa juga dapat membangun sendiri pemahaman mereka melalui interaksi langsung dengan lingkungan sekitar siswa (Sfard\&Cobb, 2014). Wijaya (2012) menyebutkan bahwa segala sesuatu yang ada di lingkungan sekitar dan dekat dengan siswa seperti benda maupun objek dapat dimanfaatkan sebagai konteks yang membantu starting point pembelajaran matematika di tingkat dasar.

Fanu (2008) menyebutkan bahwa kemampuan memanipulasi objek atau benda merupakan salah satu elemen penting yang dibutuhkan dalam belajar matematika. Pemberian kesempatan untuk mengotak atik benda di lingkungan sekitar sangat membantu proses belajar siswa untuk membangun sendiri (constructivism) dan menemukan kembali (reinvention) sebuah konsep matematika. Learning mathematics by doing something menjadikan konsep - konsep matematika dapat tertanam lebih lama dalam pikiran siswa.

Dewasa ini, seiring dengan banyaknya kesadaran para pemerhati pendidikan matematika untuk mengajarkan matematika 
yang abstrak sesuai dengan tingkat berpikir kognitif siswa di tingkat dasar, perkembangan alat peraga sebagai media pembelajaran konkrit untuk matematika mulai berkembang dengan baik. Pengetahuan tentang SCL dan konstruktivisme juga sering digaungkan dalam berbagai seminar, workshop, maupun pelatihan. Konstruktivisme menggunakan media dan peraga dalam pembelajaran menjadi salah satu opsi untuk memberikan pembelajaran matematika yang bermakna (meaningful learning) bagi siswa SD.

$$
\text { Beberapa riset tentang }
$$

kebermanfaatan media atau peraga dalam pembelajaran matematika sudah banyak kita temukan. Zuliana (2015) menyebutkan bahwa pembelajaran matematika dengan menggunakan kartu masalah sebagai media pembelajaran dipadukan dengan model Problem Based Learning (PBL) memberikan pengaruh positif terhadap kemampuan pemecahan masalah matematika siswa SD, penelitian lainnya menyebutkan bahwa media benda konkret efektif mampu meningkatkan kualitas pembelajaran matematika pada materi bangun ruang (Amalin, 2015). Peraga manipulatif juga terbukti mampu membantu mahasiswa calon guru SD dalam membangun konsep dan memahami penggunaannya untuk membelajarkan konsep geometri bangun datar bagi siswa SD (Zuliana, 2017).

Nurseto (2011:19) menyebutkan bahwa pengembangan peraga maupun media pembelajaran sendiri harus menganut prinsip VISUALS. Visible: mudah untuk dilihat atau dipegang, Interesting: menarik, Simple: sederhana, Useful: isi dari media berguna atau bermanfaat khususnya untuk proses belajar, Accurate: benar dan tepat sehingga dapat dipertanggungjawabkan, Legitimate: masuk akal dan sah, Structured: terstruktur atau tersusun dengan baik. Di samping itu, setiap peraga maupun media pembelajaran perlu dikembangkan dengan menyesuaikan karakteristik konsep yang akan dipelajari oleh siswa. Sugiarto, dkk (2012:14) menyebutkan bahwa setiap kajian dari objek matematika termasuk geometri (datar maupun ruang) yang bersifat abstrak memiliki atribut yang semestinya dapat direpresentasikan pada alat peraga sebagai model objek geometri.

Simetri putar merupakan salah satu objek kajian matematika dalam lingkup geometri terkait transformasi. Van de Walle, et.al (2007) menyebutkan bahwa transformasi merupakan perubahan pada posisi atau ukuran bentuk. Lebih lanjut Walle mengatakan sebuah bangun atau bentuk benda dikatakan memiliki simetri putar apabila dapat diputar pada suatu titik dan berakhir pada posisi yang tepat cocok seperti posisi semula. Sedangkan cara terbaik untuk memahami konsep simetri putar adalah mengambil bentuk benda/bangun seperti persegi atau yang lainnya kemudian dijiplak pada selembar kertas. Hasil jiplakan ini disebut "kotak bentuk", untuk kemudian dicari orde dari simetri putar persegi atau bangun tersebut. Orde simetri putar merupakan jumlah cara bentuk benda/bangun datar sehingga dapat masuk ke dalam kotak bentuk tanpa membalikkannya (Walle, et.al, 2007:175). Pada saat memutar benda/bangun datar, kita juga dapat menggunakan bantuan label sudut atau derajat perputarannya.

Dalam proses mendesain media pembelajaran maupun peraga, guru maupun fasilitator pembelajaran dapat memperhatikan Prinsip VISUALS dan ketepatan bentuk serta fungsi peraga dalam rangka membantu siswa membangun sendiri konsep serta membuat siswa melalui lintasan belajar yang tepat terhadap konsep tersebut.

\section{METODE PENELITIAN}

Penelitian ini merupakan design research. Design research merupakan pendekatan penelitian dimana materi terhubung dengan perkembangan teori pembelajaran (Van Eerde, 2013). Prahmana (2017:13) menyebutkan bahwa design research merupakan suatu metode penelitian yang sesuai untuk mengembangkan solusi dari suatu masalah kompleks dalam praktik pendidikan atau untuk mengembangkan dan memvalidasi suatu teori tentang proses belajar, lingkungan belajar, dan sejenisnya. Lebih lanjut Sembiring, Hoogland, \& Dolk, 2010) menyebutkan bahwa design research merupakan suatu proses siklik dari percobaan pemikiran (thought experiment) menuju percobaan pengajaran (instruction experiment). Tahapan dari design research: (1) pre eliminary design, (2) teaching experiment, dan (3) retrospective analysis (Gravemeijer \& Cobb, 2006). Pembahasan pada artikel ini dibatasi pada fase pertama yaitu pre eliminary design. Widjaja (2008) menyatakan tujuan dilakukannnya kegiatan pre eliminary design (desain pendahuluan) adalah untuk mengembangkan urutan kegiatan pembelajaran dan mendesain instrumen. Pramudiani, et.al (2014) menyatakan bahwa pada fase pertama ini runtutan proses yang dilakukan dimulai dengan merumuskan tujuan pembelajaran matematika, dikombinasikan dengan kegiatan eksperimen pemikiran antisipatif di mana seorang guru sebagai desainer pembelajaran 
membayangkan bagaimana proses kegiatan belajar mengajar dilakukan di kelas.

Literature review dilakukan untuk mendapatkan pengetahuan yang relevan terkait simetri putar serta ketepatan desain pembelajaran dengan tujuan pembelajaran (konstruksi konsep simetri putar). Ketepatan konsep yang menjadi topik pembelajaran dengan tujuan pembelajaran digunakan untuk mendesain perangkat dan media pembelajaran serta rancangan lintasan belajar (HLT) yang dilalui oleh siswa.

\section{HASIL DAN PEMBAHASAN}

Kegiatan yang dilakukan pada tahapan pertama design research (pre eliminary design) dalam rangka pembangunan konsep simetri putar menghasilkan conjectured local instruction theory yang terdiri atas tiga komponen: (a) tujuan pembelajaran bagi siswa, (b) perencanaan kegiatan instruksional dan alat atau media yang digunakan, dan (c) sebuah dugaan proses belajar hypothetical learning trajectory (HLT) dimana seorang guru/desainer pembelajaran mampu mengantisipasi bagaimana pemikiran dan pemahaman siswa agar dapat berkembang pada saat aktivitas instruksional digunakan di kelas.

\section{Tujuan Pembelajaran bagi siswa}

Membantu siswa melakukan proses konstruktivisme untuk membangun konsep pengetahuan tentang simetri putar menggunakan Siputmatika

\section{Konsep Simetri Putar Bangun Datar}

Berikut disajikan contoh konsep simetri putar dari bangun datar persegi dan persegi panjang, seperti terlihat pada gambar 1 dan 2 .

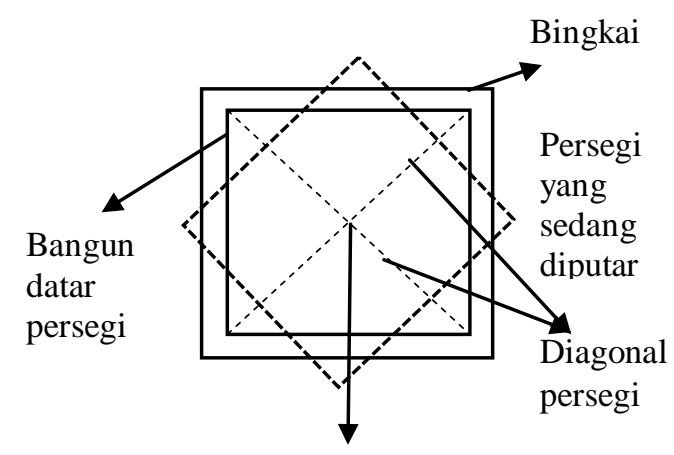

Titik pusat/ poros

Gambar 1. Simetri Putar Bangun Persegi
Persegi tersebut ketika diputar $90^{\circ}$, $180^{\circ}, 270^{\circ}$ dan $360^{\circ}$ akan menempati dengan tepat bingkainya. Sehingga orde simetri putar untuk persegi ada 4. Dalam bahasa sederhana tingkat dasar disebutkan bahwa banyaknya simetri putar pada sebuah persegi adalah 4 .

Pada gambar 2 berikut disajikan contoh proses pembangunan konsep simetri putar untuk bangun persegi panjang.

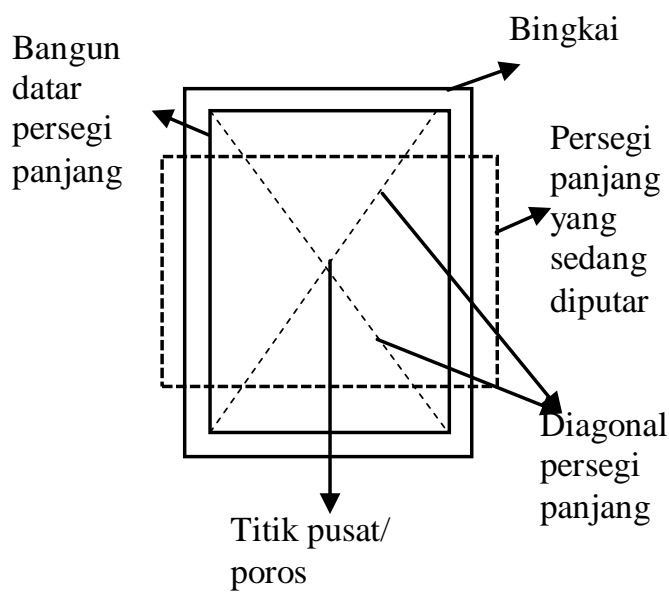

Gambar 2. Simetri Putar Bangun Persegi Panjang

Persegi panjang tersebut ketika diputar $180^{\circ}$ dan $360^{\circ}$ akan menempati dengan tepat bingkainya. Sehingga orde simetri putar untuk persegi panjang adalah 2. Dalam bahasa sederhana banyaknya simetri putar pada sebuah persegi panjang adalah 2 .

\section{Siputmatika}

Pertimbangan dalam mendesain pembelajaran simetri putar untuk siswa di SD adalah tingkat berpikir kognitif siswa SD. Piaget (2000) menyebutkan anak usia 6-12 tahun yang berada pada fase operational concrete, penggunaan pendekatan dan strategi belajar yang tepat untuk siswa SD yang berada pada fase ini adalah student centered learning (SCL) (Nanney, 2004). Dengan penekanan pada constructivisme akan terjadi reinvention (Moreno \& Waldegg, 1993; Freudenthal 2006) sehingga menghasilkan pembelajaran yang bermakna (meaningful learning). Oleh karena itu, desain media pembelajaran yang tepat dengan konsep dapat membantu siswa SD membangun sendiri konsep simetri putar.

Oleh karena itu, didesain sebuah media pembelajaran Simetri Putar Matematika (Siputmatika). Siputmatika didesain dengan memperhatikan syarat dan prinsip pembuatan media pembelajaran seperti disebutkan oleh Nurseto (2011) yaitu prinsip 
VISUALS (visible sehingga mudah dilihat dan dipegang, mampu menarik perhatian siswa (interesting), tidak rumit/sederhana (simple), bermanfaat untuk membantu siswa belajar membangun konsep simetri putar (useful), esuai atau tepat dengan konsep materi simetri putar (accurate), masuk akal (legitimate) dan tersusun dengan baik tidak sembarangan (structured).

Peraga siputmatika ini juga relatif kuat, tidak mudah rusak dan tahan lama, karena dibuat dari bahan kayu. Dari sisi content dan konsep media ini, dilengkapi dengan poros atau titik pusat sebagai pusat untuk memutar, sudut perputaran (rotasi) digunakan untuk membantu siswa melihat sejauh mana media diputar, bingkai bangun datar yang digunakan sebagai acuan. Bingkai bangun datar ini mempunyai bentuk menyesuaikan bentuk bangun datar yang akan ditentukan jumlah simetri putarnya. Berikutnya dalam siputmatika ini juga terdapat kantong aturan main yang terletak di sebelah kiri. Kantong ini digunakan sebagai petunjuk penggunaan peraga siputmatika. Kantong sebelah kanan adalah kantong bangun datar yang berisi berbagai jenis bangun datar seperti persegi, persegi panjang, segitiga siku - siku, berbagai jenis segitiga seperti segitiga sama kaki, segitiga sama sisi, segitiga sembarang, jajar genjang, belah ketupat, layang - layang, trapesium sembarang, trapesium sama kaki, trapesium siku - siku, lingkaran dan lingkaran.

Berikut pada gambar 3 disajikan desain peraga siputmatika.

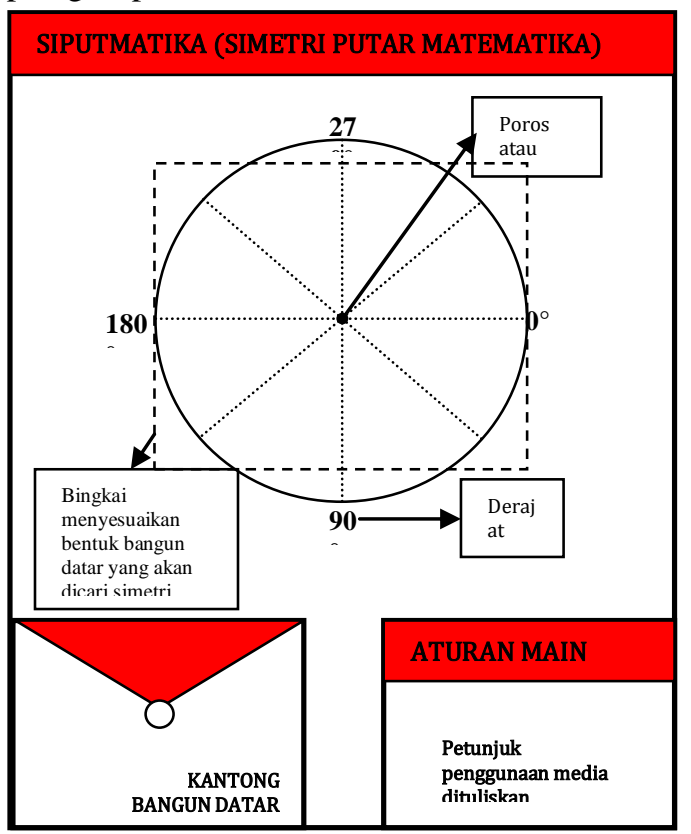

Gambar 3. Desain Siputmatika

\section{Learning Design Konsep Materi Simetri Putar menggunakan Siputmatika}

Adapun rancangan kegiatan

instruksional/ pembelajaran matematika SD materi simetri putar adalah sebagai berikut.

1. Pengingatan kembali materi prasyarat terkait jenis - jenis dan bentuk bangun datar

2. Proses pembangunan konsep simetri putar menggunakan siputmatika oleh siswa sendiri (constructivisme menggunakan objek konkrit yang menghasilkan reinvention) dilakukan dengan:

a) Membaca aturan main siputmatika

b) Menentukan bangun datar yang akan dicari simetri putarnya dengan mengambil salah satu bangun datar yang ada di dalam Kantung Bangun Datar

c) Menemukan bingkai bangun datar yang sesuai. Misalkan bangun datar yang diambil persegi berarti bingkai yang diambil juga persegi

d) Menempel bagian tengah bangun datar di titik pusat/poros. Mencocokan dengan bingkai bangun datar yang sesuai.

e) Memutar bangun datar searah jarum jam

f) Menemukan konsep simetri putar dari bangun datar

g) Berpikir dilanjutkan bernalar sampai menemukan banyaknya simetri putar pada bangun datar tersebut

3. Menuliskan hasil ke dalam tabel simetri putar bangun datar

4. Mengkomunikasikan ke teman/siswa lain terkait hasil temuan

5. Penarikan kesimpulan

Rancangan Lintasan Belajar: Hypothetical Learning Trajectory (HLT) Materi Simetri Putar Bangun Datar bagi Siswa Sekolah Dasar Dasar

HLT Simetri Putar Bangun datar dapat dilihat pada Tabel 1 berikut. 
Tabel 1. HLT Simetri Putar Bangun Datar pada Siswa Sekolah Dasar Menggunakan Siputmatika

\begin{tabular}{|c|c|c|c|c|}
\hline No & $\begin{array}{c}\text { Tujuan } \\
\text { Pembelajaran }\end{array}$ & $\begin{array}{c}\text { Kegiatan } \\
\text { Pembelajaran }\end{array}$ & Dugaan/hypothesis & Konsep \\
\hline 1 & $\begin{array}{l}\text { Siswa mampu } \\
\text { mengingat kembali } \\
\text { jenis dan bentuk } \\
\text { bangun datar }\end{array}$ & $\begin{array}{l}\text { Melalui pengamatan, } \\
\text { siswa mengamati } \\
\text { beberapa bangun } \\
\text { datar untuk } \\
\text { kemudian mencari } \\
\text { bingkai bangun datar } \\
\text { yang sesuai }\end{array}$ & $\begin{array}{l}\text { - Siswa mampu } \\
\text { menyebutkan jenis dan } \\
\text { bentuk bangun datar serta } \\
\text { menemukan dengan tepat } \\
\text { bingkai bangun datar } \\
\text { yang sesuai } \\
\text { - Siswa mengalami } \\
\text { keterbalikan konsep } \\
\text { antara bangun persegi } \\
\text { dan persegi panjang }\end{array}$ & $\begin{array}{l}\text { Ketepatan jenis dan } \\
\text { bentuk bangun datar: } \\
\text { persegi, persegi } \\
\text { panjang, segitiga, } \\
\text { belah ketupat, jajar } \\
\text { genjang, layang - } \\
\text { layang, trapesium dan } \\
\text { lingkaran }\end{array}$ \\
\hline 2 & $\begin{array}{l}\text { Siswa mampu } \\
\text { menemukan konsep } \\
\text { simetri putar }\end{array}$ & $\begin{array}{l}\text { Melalui percobaan } \\
\text { (eksperimen) siswa } \\
\text { menggunakan } \\
\text { siputmatika untuk } \\
\text { mencari konsep } \\
\text { simetri putar dari } \\
\text { suatu bangun datar }\end{array}$ & $\begin{array}{l}\text { - Siswa mampu memutar } \\
\text { dengan benar sesuai } \\
\text { petunjuk penggunaan } \\
\text { peraga siputmatika, untuk } \\
\text { selanjutnya mendapatkan } \\
\text { konsep simetri putar } \\
\text { ketika bangun datar } \\
\text { tersebut mampu } \\
\text { menempati bingkainya } \\
\text { dengan tepat }\end{array}$ & Konsep simetri putar \\
\hline 3 & \begin{tabular}{|l|} 
Siswa mampu \\
menentukan jumlah \\
simetri putar \\
bangun datar
\end{tabular} & $\begin{array}{l}\text { Melalui percobaan } \\
\text { (eksperimen) siswa } \\
\text { menggunakan } \\
\text { siputmatika untuk } \\
\text { menemukan } \\
\text { banyaknya simetri } \\
\text { putar bangun datar }\end{array}$ & $\begin{array}{l}\text { Setelah mengetahui } \\
\text { konsep simetri putar, } \\
\text { siswa mampu melakukan } \\
\text { percobaan menentukan } \\
\text { jumlah/ banyaknya } \\
\text { simetri putar bangun } \\
\text { datar } \\
\text { - Ada ketidaktepatan } \\
\text { konsep banyaknya } \\
\text { simetri putar suatu } \\
\text { bangun datar }\end{array}$ & $\begin{array}{l}\text { Banyaknya simetri } \\
\text { putar bangun datar }\end{array}$ \\
\hline
\end{tabular}


Adapun rancangan lintasan belajar (learning trajectory) simetri putar menggunakan Siputmatika adalah sebagai berikut.

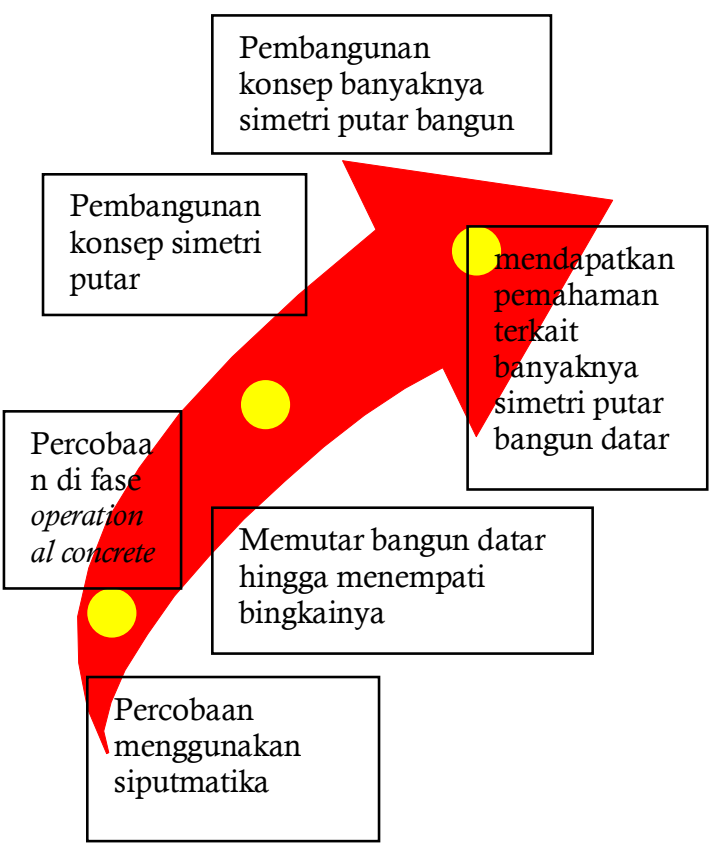

Gambar 4. Lintasan Belajar Simetri Putar menggunakan Siputmatika

\section{SIMPULAN}

Dihasilkan rancangan lintasan belajar (learning trajectory) materi simetri putar menggunakan Siputmatika bagi siswa Sekolah Dasar dari hasil kegiatan pada fase pre eliminary design (desain pendahuluan). Dugaan lintasan belajar yang akan dilalui oleh siswa pada pembelajaran menggunakan Siputmatika ini dapat dijadikan oleh guru SD sebagai rambu - rambu dalam pembelajaran matematika materi simetri putar

\section{DAFTAR PUSTAKA}

Amalin, K. 2015. Penerapan Pendekatan Saintifik Dengan Media Benda Konkret Dalam Peningkatan Pembelajaran Matematika Tentang Bangun Ruang Pada Siswa Kelas V SDN Kalijambe Tahun Ajaran 2014/2015. Kalam Cendekia PGSD Kebumen, 3(2.1): 181186.

Bethari, A. 2015. Laporan Observasi Diagnosis Kesulitan Belajar Matematika Siswa Kelas V Sekolah Dasar.
Barrouillet, P. 2015. Theories of cognitive development: From Piaget to today, Developmental Review, Vol.38: 1-12.

Freudenthal, H. 2006. Revisiting mathematics education: China lectures (Vol. 9). Springer Science \& Business Media.

Fanu, J. L. 2002. Deteksi dini masalah-masalah psikologi anak. Yogyakarta: Think.

Gravemeijer, K. \& Cobb, P. 2006. Design research from a learning design perspective. In J. Van den Akker, K. Gravemeijer, S. McKenney \& N. Nieveen (Eds.), Educational design research. London, England: Routledge

Heruman. 2012. Model Pembelajaran Matematika di Sekolah Dasar. Bandung: PT Remaja Rosda Karya.

Larsen, S., \& Zandieh, M. 2008. Proofs and refutations in the undergraduate mathematics classroom. Educational Studies in Mathematics, 67(3): 205-216.

Moreno- Armella, L., \& Waldegg, G. (1993). Constructivism and mathematical education. International Journal of Mathematical Education in Science and Technology, 24(5), 653-661.

Nanney, B. (2004). Student-centered learning. Retrieved November, 30, 2012.

Nurseto, T. 2012. Membuat media pembelajaran yang menarik. Jurnal Ekonomi \& Pendidikan, 8(1): 19-35.

Novak, J. D. 2002. Meaningful learning: The essential factor for conceptual change in limited or inappropriate propositional hierarchies leading to empowerment of learners. Science education, 86(4): 548571.

Piaget, J. (2000). Piaget's theory of cognitive development. Childhood cognitive development: The essential readings, 33 47.

Prahmana, RCI. 2017. Design Research (Teori dan Implementasinya: Suatu Pengantar). Depok: Rajawali Press.

Pramudiani, P., Zulkardi, Z., Hartono, Y., \& Amerom, B. V. 2014. A Concrete 
Situation For Learning Decimals. Journal on Mathematics Education, 2(2), 215-230.

Sembiring, R., Hoogland, K., \& Dolk, M. L. A. M. (Eds.). (2010). A decade of PMRI in Indonesia. Bandung, Utrecht: Ten Brink, Meppel.

Sfard, A., \& Cobb, P. 2014. Research in mathematics education: What can it teach us about human learning. The Cambridge Handbook of the Learning Sciences, 545-63.

Sugiarto. 2009. Bahan Ajar Workshop Pendidikan Matematika 1. Semarang: Universitas Negeri Semarang.

Sugiarto, dkk. 2012. Pembelajaran Geometri Berbasis Enaktif, Ikonik, Simbolik Untuk Menumbuhkan Kemampuan Berpikir Kreatif Peserta Didik Sekolah Dasar. Journal of Primary Education, 1(1): 12-18.

Van de Walle, J. A., Karp, K. S., \& Williams, J. M. B. 2007. Elementary and middle school mathematics. Teaching development. Boston: Pearson.

Van Eerde, D. 2013. Design research: Looking into the heart of mathematics education. Proceeding The First South East Asia Design/Development Research (SEA-
DR) International Conference, Palembang: Sriwijaya University, 1-11.

Widjaja, W. 2008. Local instruction theory on decimals: The case of Indonesian preservice teachers (Doctoral dissertation). Melbourne Graduate School of Education, The University of Melbourne.

Wijaya, A. 2012. Pendidikan matematika realistik: Suatu alternatif pendekatan pembelajaran matematika. Yogyakarta: Graha Ilmu.

Zuliana, E., \& Bintoro, H. S. 2013. Pembelajaran Matematika Realistik Berkonteks Selendang Toh Watu Pada Materi Luas Daerah Persegi Panjang Di Kelas III SD 1 Purworejo Kudus. Sendimat.

Zuliana, E. 2015. Pengaruh Model Problem Based Learning Berbantuan Kartu Masalah Terhadap Kemampuan Pemecahan Masalah Matematika Siswa Sekolah Dasar. Refleksi Edukatika, 5(1).

Zuliana, E. 2017. Penerapan Inquiry Based Learning berbantuan Peraga Manipulatif dalam Meningkatkan Pemahaman Konsep Matematika pada Materi Geometri Mahasiswa PGSD Universitas Muria Kudus. Lectura: Jurnal Pendidikan, 8(1): 35-43. 